\title{
Implementing the humanitarian potential of mathematics in the training of elementary school teachers
}

\author{
Lubov Vasilievna Shatunova ${ }^{1 *}$, Marina Aleksandrovna Romanova ${ }^{2}$, Vita Immanuilovna \\ Glizburg $^{2}$, and Ekaterina Vladimirovna Ryabova ${ }^{3}$ \\ ${ }^{1}$ Sakhalin State University, Department of Theory and Methods of Training and Education, Yuzhno- \\ Sakhalinsk, Russia \\ ${ }^{2}$ Moscow City Pedagogical University, Institute of Pedagogy and Psychology of Education \\ Psychological Sciences, Moscow, Russia \\ ${ }^{3}$ Abay Kazakh National Pedagogical University, Institute of Pedagogy and Psychology, Department \\ of Professional Training Educational program "Elementary education”, Almaty, Kazakhstan
}

\begin{abstract}
The complex concept of "the humanitarian potential of mathematics" needs to update the educational environment of elementary schools and universities, as well as the relationship of participants in the educational process. The humanization of natural sciences requires the development of new elective courses, cognitive tasks, various dialogues and search activities of participants in the learning process. In the context of mathematics, this phenomenon has many meanings. The main direction in this research is the paradigm of personality-oriented education aimed at the development of general cultural components and the formation of students' values-based attitude to the surrounding world. While considering the humanitarian potential of mathematics, it is important to take into account its aesthetic, historical, linguistic, activity-based and applied components. The authors of the article dwell on the linguistic component of humanitarian mathematics. They describe a new teaching method improving the speech of a mathematics teacher of elementary school. In addition, the authors consider the possibilities of using the digital educational platform Yandex.Textbook as a source of modern didactic materials and various representations of mathematical knowledge. By using the content of Yandex.Textbook in extracurricular activities and elective courses in mathematics, it is possible to develop the creative imagination of students and expand their cultural horizons. Despite a large number of mathematics textbooks for elementary school, there is a need to create an educational complex based on the humanization of mathematics education. The same task is solved by the developers of teaching aids and elective courses for students, i.e. future mathematics teachers.
\end{abstract}

Keywords: potential of humanitarian mathematics, linguistic aspect, mathematical speech, consideration of a speech culture.

\footnotetext{
*Corresponding author: shatunovvs@yandex.ru
} 


\section{Introduction}

The formation of a scientific worldview of students was considered by A.G. Asmolov, B.M. Bim-Bad, N.N. Moiseev, T.D. Rassadina, K.A. Reznichenko, V.I. Saratovskii, E.V. Ushakova, N.A. Shkilmenskaya, etc [1].

Certain aspects of education humanization were analyzed by S.I. Hessen, L.L. Kasyan, V.E. Klochko, I.D. Kolesnikova, G.V. Lavrentev, Yu.V. Senko, etc.

The ideas of personality-oriented pedagogy were reflected in the scientific works of D.A. Belukhin, E.V. Bondarevskaya, V.A. Bukhvalov, P. Grossman, K.P. Dean, S.S. Kavanagh, A.I. Savenkov, N. Hensley, S. Herrmann, I. S. Yakimanskaya, etc [2, 3].

E.V. Baranova, G.M. Volkov, V.I. Glisburg, N.V. Guseva, L. Darling-Hammond, S.D. Deryabo, O.L. Kazanskii, M.V. Klarin, S.V. Menkova, P.G. Nikiforova, N. Pachler, E.S. Samoilova, K. Turvy, N.A. Khomuttsova, A.A. Shapovalova, O. Fedchishin [4-11] and other scholars described new trends in pedagogy that allow reaching the humanitarian level significant for society.

M.A. Romanova's works $[12,13]$ are concerned with the teacher's adequate idea of how to use one's psychological and pedagogical potential and successfully implement it for teaching and upbringing children. The author wrote, "While studying at a pedagogical university, a student as a future elementary school teacher receives a large amount of general and special psychological and pedagogical knowledge, which allows to professionally and competently teach and educate children at a modern scientific and methodological level" [14: 86]. However, a novice teacher often focuses only on general, theoretical knowledge when teaching mathematics and does not take into account the challenges of the time.

Three or four decades ago, didactic material in mathematics did not differ much in terms of text components for elementary school textbooks. However, the end of the $20^{\text {th }}$ century and the beginning of the $21^{\text {st }}$ century are characterized by a large number of new approaches and, accordingly, new mathematics textbooks for elementary school which replaced arithmetic and expanded the general concept of mathematics for students. They included a sufficient number of tasks for developing computational skills and improved task descriptions (various objects and concepts from the modern world emerged instead of tables, chairs, tomatoes and apples).

Some sections of elementary geometry included in mathematics courses provide topological tasks to determine closed figures or bounded sets, in particular, closed broken lines. Visualization technologies of graphic packages establish the fact of "ink creeping" during painting, the latter means a closed figure. Such tasks aim at developing the child's ability to navigate in space; to select from the set of given figures according to various criteria: certain properties, for example, closed, bounded or open; to perform certain actions with shapes, for example, forming a whole or cutting into parts, coloring, etc. The competences formed throughout learning to solve such geometric tasks ensure the implementation of an elementary mathematics course, which is one of its basic humanitarian components. While visualizing and describing the process of solving the above-mentioned tasks, it is possible to develop aesthetic and linguistic components of the humanitarian potential of mathematics through the introduction of basic topological knowledge into the learning process. This helps future teachers form a "special worldview, understand the logic of the world, natural processes, continuous interconnections, promotes the teacher's inclusion in the educational and cultural environment both as a carrier of mathematical knowledge and a translator of culture based on the inter-subjective exchange of values, notions and skills" [5: 7-8].

In the late 1980s, Russia introduced the concept of "humanization" within the framework of its educational reform and the restructuring of education. It meant "the turn of education towards a holistic worldview (i.e. the world of culture, the world of a person), humanizing 
knowledge, forming humanitarian and systemic thinking" [15: 14]. In the early 2000s, the Russian educational system moved to a new level based on the competency-based approach to learning. The theoretical concept of "interdisciplinary connections" became real and gave rise to the new concept of school mathematics education. The latter claims that "the main direction of restructuring the content and method of teaching mathematics is the implementation of its close connections with practical activity and diverse connections with the environment, the reorientation of teaching to an individual, strengthening the cultural and educational significance of the material under study" [4:28].

\section{Methods}

The linguistic aspect in any discipline is associated with increased attention to oral and written speech. When working with students, it is recommended to use reasoning dialogues (based on explanatory dictionaries) and excerpts from children's speech to introduce them to the issues of linguoecology. For example, students widely use colloquial plural forms of the genitive case помидор, килограмм, гектар (pomidor, kilogram, gektar/tomato, kilogram, hectare, etc.) in their oral speech. To consolidate linguistic rules, it is important to keep verbal records and draw up cards with comments on colloquial norms in mathematics tasks instead of the generally accepted abbreviations ( $\mathrm{kg}, \mathrm{g}$, ha).

Below are some examples of careful word choice when training elementary school teachers.

In the Russian language, there are two words "ноль" and "нуль" (nol and nul/zero) often placed in one dictionary entry. Students can make a map of reasoning on the following topic: "Is the free use of nol/nul variants in the Russian language and mathematics the same?".

Throughout the history of the Russian language, both words were used with the same frequency and practically no differences in interpretation. There is no unambiguous codification of lexical variants in modern Russian. Although many dictionaries describe $n u l$ as a lexical unit commonly used in exact sciences, nol is used in modern school mathematics. The "nol" word is a digital sign and a term denoting no quantity. The use of this pair of words in mathematical speech is quite specific. Both options can be used in calculations, for example: to add 0 to $20,0.8$, to subtract 0.13 , the division by zero is undefined, etc. There are also such expressions as to reduce to zero, to make calculations with zero, to set to zero.

In linguistics, "nol" and "nul" do not differ in meaning but rather in their usage. D.E. Rozental explained the use of these words in the following way: "As a rule, nol is used in everyday speech and several set phrases, while nul is more common to scientific terms. Compare: ноль внимания/nol vnimaniya (colloquial); ноль без палочки/nol bez palochki (colloquial) - to set to zero, equal to zero" [14]. S.I. Ozhegov's explanatory dictionary provides these words in the entry "Nol and Nul". The coordinating conjunction proves their same meaning. It is quite interesting that there are variants in diminutive forms нолик and нулик (nolik and nulik) but only one adjective нулевой (nulevoi).

In the $21^{\text {st }}$ century, the use of $n o l$ prevails but its lexical doublet $n u l$ is noticeably falling out of use. However, the latter is actively used in such word combinations as nullification. $\mathrm{Nul}$ has more forms, while nol can be used only in singular forms of the nominative and accusative cases.

Indeed, the use of "nol" and "nul" in the Russian language in general and mathematics, in particular, requires comprehensive analysis, but drawing attention to these words realizes the humanitarian potential of mathematics. Teachers can give students tasks aimed at developing their cognitive interest: "How 0 is designated in mathematics? Give examples from various sources to show the different use of nol and nul".

To compare the potential of different words expressing common and limited aspects, it is a good idea to refer to children's creativity. This can be exemplified by children's literature: 
"Raz moroznoyu zimoi Vdol opushki lesnoi Shel medved k sebe domoi V teploi shube mekhovoi"; "Edu s mamoi v zoosad I schitayu vsekh podryad. Probegaet dikobraz. Eto - raz. Chistit peryshki sova, Eto - dva. Tretei stala rosomakha. A chetvertoi - cherepakha. Seryi volk ulegsya spat. Eto - pyat. Popugai v listve gustoi, On - shestoi"/ Once in a frosty winter Along the edge of the forest A bear walked to his home In a warm fur coat"; "I am going with my mother to the zoo And I count everyone in a row. A porcupine runs by. This is one. An owl cleans the feathers. This is two. The third is the wolverine. And the fourth is the turtle. The gray wolf went to bed. This is five. The parrot sits in dense leaves. It is the sixth" (V. Orlov "I count"). In the first context, $\mathrm{pa} / \mathrm{raz}$ is an adverb used in the meaning of "once, one time". V. Orlov used $\mathrm{raz}$ in the meaning of the numeral oduн/odin (one). The text reflects the specifics of children's speech: the mixed use of quantitative and ordinal numerals (a child simultaneously counts animals and indicates the order when counting). These examples explain to students that the raz word can have multiple meanings: a single action (when counting); an event or phenomenon in a series of repetitive actions; one. The work with the phraseological meaning of the raz word contributes to the development of a linguistic feeling: $v$ samyi raz - on time or just right (colloquial); raz i navsegda (colloquial) - finally or decisively; raz, dva i gotovo (colloquial, joking) - it is said about what can be done very quickly or what is done quickly. Colloquial $\mathrm{raz}$ can be used in a complex sentence in the meaning of eсли/esli (if). Compare: the colloquial, obsolete conjunction koli/kol: Raz nachal govorit-govori. Koli ty tak, tak i ya tak; a koli ty tak, tak $i$ ya edak (If you began to speak, speak. If you do it, so am I; and if you do that, so will I).

\section{Results}

We have provided several examples to develop language and stylistic skills of both future elementary school teachers and elementary school students. The results of assessing the creative thinking of future elementary school teachers correlate with the results obtained by foreign scholars. However, scholars from other countries do not focus on additional didactic capabilities of non-standard tasks. If students form them independently, it can have a positive impact on the development of their combinatorial thinking. In this case, we should highlight the greatest effect of the joint experimental work of two large Russian universities.

These tasks stimulate their abilities for divergent thinking and develop combinatorial abilities through competences in such spheres as algebra, geometry, mathematical analysis and mathematical statistics, as well as general humanitarian training and awareness of the current processes and phenomena.

While referring to the general cultural component of humanitarian mathematics, it is worth mentioning that the same mathematical content should be given a more entertaining form. This task is solved by the scientifically grounded inclusion of modern information and educational platform Yandex.Textbook in the educational process as an additional didactic source. Non-standard tasks, rebuses, quests and puzzles provide an opportunity to develop the creative thinking of younger students. Tasks with varying degrees of difficulty help the teacher find an individual approach to each child and reveal their potential. The main advantage of the mathematics tasks for elementary school presented on Yandex.Textbook is their non-standard text representation. The content of such tasks attracts children with its relevance, stimulates the creative imagination, develops their logic and spatial thinking. Here is an example of solving problems opposite to the given one (Fig. 1). 


\section{Mark the given information in each task}

1) While visiting the zoo, Gosha took six selfies with tigers and eight selfies with hippos. How many selfies did Gosha take?
The number of tiger selfies

The number of hippo selfies
The total number of selfies

2) While visiting the zoo, Gosha took 14 selfies with different animals. There were six selfies with tigers, while the remaining selfies were with hippos. How many selfies with hippos did Gosha take?

The number of tiger selfies
The number of hippo selfies
The total number of selfies

3) While visiting the zoo, Gosha took 14 selfies with different animals. There were eight selfies with hippos, while the remaining selfies were with tigers. How many selfies with tigers did Gosha take?

The number of tiger selfies
The number of hippo selfies
The total number of selfies

Fig.1. Example of the tasks

\section{Conclusion}

The increasing technologization and digitalization of society condition the corresponding spiritual and ecological progress. The humanization of education is a complex and multicomponent phenomenon associated with the search activity of students and teachers, the creative educational and cognitive activity of students. To implement the humanitarian potential of mathematics, it is necessary to form guides containing tasks for the development of mathematical speech of future elementary school teachers and elective courses on a given topic for students (future mathematics teachers).

\section{References}

1. N.A. Shkilmenskaya, Gumanitarnyi potentsial kursa algebry i nachal analiza profilnoi shkoly. Model, printsipy i osobennosti realizatsii [The humanitarian potential of algebra courses and elements of analysis at profession-oriented school. Models, principles and specifics of implementation] (Pomorskii universitet, Arkhangelsk, 2007)

2. P. Grossman, C.P. Dean, S.S. Kavanagh, Z. Herrmann, Phi Delta Kappan, 100(7), 4348 (2019)

3. N. Hensley, Journal of Cleaner Production, 243118542 (2020). https://doi.org/10.1016/j.jclepro.2019.118542 
4. E.V. Baranova, N.V. Guseva, S.V. Menkova, Gumanitarnyi potentsial shkolnogo kursa matematiki i ego realizatsiya $\mathrm{v}$ obuchenii [The humanitarian potential of mathematics and its implementation in student courses] (Arzamasskii filial NNGU, Arzamas, 2014)

5. V.I. Glisburg, Gumanitarnyi potentsial topologicheskoi podgotovki uchitelya [The humanitarian potential of the topological training of teachers] (Pero, Moscow, 2019)

6. J. Bransford, S. Derry, D. Berliner, K. Hammerness, K.L. Beckett, Theories of learning and their roles in teaching, in L. Darling-Hammond, J. Bransford (eds.), Preparing teachers for a changing world, 40-87 (Jossey-Bass, San Francisco, 2005)

7. P.G. Nikiforova, Humanization and humanitarization of natural and technical education chemical technologies and nanomaterials, in The materials of the international conference. North-Eastern Federal University named after M.K. Ammosov 2014, Stavropol, 75-80 (2014)

8. K. Turvey, N. Pachler, Computers \& Education, 146 (2020). https://doi.org/10.1016/j.compedu.2019.103736

9. V.I. Glisburg, E.S. Samoilova, Vestnik Rossiiskogo universiteta druzhby narodov, Seriya: Informatizatsiya obrazovaniya, 3, 85-91 (2016)

10. N.A. Khomuttsova, Pedagogicheskie usloviya gumanitarizatsii shkolnogo estestvennonauchnogo obrazovaniya [Pedagogical conditions for the humanization of natural science education at school]: thesis for a Candidate Degree in Pedagogical Sciences (Altaiskii Gosudarstvennyi Universitet, Barnaul, 2005). Accessed on: February 28, 2021. [Online]. Available:

http://www.dissercat.com/content/pedagogicheskie-usloviya-gumanitarizatsiishkolnogo-obrazovaniya

11. O. Fedchyshyn, Scientific letters of academic society of Michal Baludansky, 6, 28-31 (2018). Accessed on: February 28, 2021. [Online]. Availablle: http://dspaca.tnpu.edu.ua/bitstream/123456789/14113/1/fed_specific_aspects_2018.pdf

12. M.A. Romanova, Modelirovanie psikhologo-pedagogicheskogo potentsiala [Modelling psychological and pedagogical potential] (SakhGU, Yuzhno-Sakhalinsk, 2013)

13. A.I. Savenkov, M.A. Romanova, Vestnik Tambovskogo Universiteta, Seriya: Gumanitarnye nauki, 7(75), 234-238 (2009)

14. D.E. Rozental, Spravochnik po pravopisaniyu i stilistike [Guide to spelling and stylistics] (n.d.). Accessed on: February 28, 2021. [Online]. Availablle: http://www.rosental-book.ru/ortho_x.html\#sect45.7

15. Vestnik obrazovaniya, 10, 2-25 (1992) 